\title{
Quality of Health Medical Services at Pediatric Cardiology Unit, Zagazig University Inpatient
}

\author{
Norhan Ahmed Elsayed Elewa*1, Amr Megahed Abu EINaga ${ }^{1}$, \\ Ahmed AbdElSamad Elhewala ${ }^{1}$, Mona Hamed Ibrahim Mohamed ${ }^{2}$ \\ Departments of ${ }^{1}$ Pediatrics and ${ }^{2}$ Community, Environmental and \\ Occupational Medicine - Faculty of Medicine, Zagazig University \\ *Corresponding author: Norhan Ahmed Elsayed Elewa, Mobile: (+20)01060319679, E-Mail: noraelewa8@ gmail.com
}

\begin{abstract}
Background: Patients' satisfaction represents an important indicator for the quality of health care delivery, and it is a widely accepted factor, which needs to be studied repeatedly for better functioning of health care systems. Patient is the best judge for the quality of health care so the factors affecting patients' satisfaction must be taken in consideration. Objective: The aim of this study was improvement of quality of the health care services provided to children in Pediatric Zagazig University Hospital.

Patients and methods: This study was a cross sectional study that was held a sample of Cardiology Unit at Pediatric Department of Zagazig University Hospitals. It was carried out during the period from July 2018 to April 2019 on a total sample of 106 patients attending Zagazig University Hospital Cardiology Unit at Pediatric Department.

Results: Among 106 participants $100 \%$ were females, $70.8 \%$ were secondary educated, $73.5 \%$ were non-workers, $55.7 \%$ were of low social class, $69.8 \%$ were from rural resident and $76.4 \%$ had not enough income with mean age of $24.48 \pm 4.5$ years. It was concluded that most of the studied patients $(89.6 \%)$ were satisfied about the studied cardiology unit at pediatric department. It was found that patient satisfaction is affected by sociodemographic factors as age, sex, occupation, education, and social class. In addition, it was affected by satisfaction about environment, facilities, treatment, doctors, nurses, administrative personnel and information given for them.

Conclusion: It was concluded that most of the studied patients are loyal to Zagazig University Hospital, as they will definitely intend to reuse and recommend Zagazig University Hospital Outpatient Clinics to others. Patient loyalty was found to be significantly affected by level of their satisfaction where satisfied patients tend to re-use and recommend the hospital Cardiology Unit at Pediatric Department more than dissatisfied ones.
\end{abstract}

Keywords: Quality of health medical services, Pediatric Cardiology Unit, Patients' satisfaction.

\section{INTRODUCTION}

Quality of care must be defined in the light of the providers' technical standards and patients' expectation ${ }^{(1)}$. While there is no single definition of health service quality applies in all situations, the most comprehensive and perhaps the simplest definition of quality is that used by advocates of total quality management: Doing the right thing right, by right way ${ }^{(2)}$.

Quality of health care is an important part of an efficient system, continuous evaluation of patients' perceptions of various dimensions of received services is necessary for raising the quality of health care. Patients' experiences are a useful basis for improving the quality of health services ${ }^{(3)}$. Patients can play an active role in the way health care is implemented, and they contribute to defining quality of care, not only on a technical level, but also on a cultural one. Understanding and satisfying their needs are essential for achievement of adequate quality of car (4). Evaluating patients' experiences provides vital information on their perception of the quality of care and treatment provided by the health care providers and the hospital as a whole. Factors affecting the provision of quality pediatric care cannot be adequately addressed without establishing the parents' perspectives on the quality of care that their children receive ${ }^{(5)}$.
Patients' health care outcomes are determined by the structural attributes of the settings in which care occurs and the processes of care ${ }^{(6)}$. According to the model by Avedis Donabedian, measurement of health care quality is based on the structures, processes of care, and outcome ${ }^{(7)}$. By interviewing the patients, information about the structures and processes and their influence on care outcome can be obtained ${ }^{(6)}$. The structures include the physical ward environment and the resources required for pediatric treatment. Patient care processes include interactions between caregivers and patients. These rely on the structures to provide resources and mechanism for those involved to be able to carry out patient care activities that aim at outcomes such as promotion of recovery, functional restoration, survival, and patient satisfaction. Care processes involving the way care is delivered include the technical and interpersonal aspects ${ }^{\left({ }^{(8)}\right.}$.Technical aspects involve timeliness and accuracy of diagnosis, coordination of care as well as appropriateness of therapy. Whereas interpersonal aspects involve clinician-patient relationship, information, and involvement in decisionmaking ${ }^{(\boldsymbol{b})}$. One of the outcomes of the care according to Donabedian includes client satisfaction. This is of great importance when measuring the quality of care. It provides information about the success of the health care provided 
about meeting the client's needs and expectations. If patients are not satisfied, then health care is regarded to have not achieved its goal ${ }^{(9)}$.

This study aimed to improve the quality of health care at Zagazig University hospitals through assessing the in-patients' satisfaction level with medical care received in in-patient clinics at Zagazig University hospitals, and determining factors affecting it.

\section{SUBJECTS AND METHODS}

This study was a cross-sectional study carried out in Inpatient Cardiology Unit of Pediatric, Zagazig University Hospitals, Sharkia Governorate from start of July 2018 to end of April 2019.

The study was conducted on 106 patients (after estimating the sample size) who attend Pediatric Cardiac Department at Zagazig University Hospitals seeking medical services to assess their level of satisfaction and quality of the provided services. In addition, the study was conducted on health care providers' doctors (5), nurses (11), worker (3) and employee (1).

Inclusion criteria: Patients admitted to Cardiac Unit of Pediatric Department, Zagazig University Hospital

Exclusion criteria: Patients with duplicate admissions during the study period were being excluded.

Sample size: By assuming that number of patients attending to pediatric cardiac unit was 230 in the past six months, and percent of perceived low quality of service was $(15 \%)$ the sample was estimated to be 106 patients using epi info 7 program with test power $80 \%$ and confidence interval (ci) $95 \%$.

\section{Sampling technique:}

Systematic random sampling technique was used. The attendance rate of patients to pediatric cardiac unit was 230 in the past six months so $46 \%$ of the total sample size (230 patients) was 106 patients. They were taken from Pediatric Cardiac Department. There were 60 health care providers' doctors, nurses, workers and employees in Pediatric Cardiac Department and 20 of them were taken from Pediatric Cardiac Department. The number of patients was selected by proportional allocation using systematic random sampling.

\section{Operational design:}

The researcher presented herself to all participants included in this study and asked them to participate after illustrating the goal of the study. The two questionnaires sheets were filled from each of them. It took about 15-20 minutes from each participant to finish the questionnaire. All selected participants received comprehensive information regarding the nature, objective and the expected benefit of the study. All ethical considerations were taken throughout the whole work.

Tools:

The data were collected through interviewing the patients and filling these questionnaires:
1- Socio-demographic questionnaire (10): For the socioeconomic characteristics of the studied participants such as age, sex and residence, educational level, occupation and income.

2- A generic assessment questionnaire ${ }^{(\mathbf{1 1})}$ that included:

- Items covering personal data.

- Items covering length of staying in hospital.

- Items covering transportation and distance from hospital.

- Items on care in Outpatient Department.

- Items on reason for admission.

- Items on the ward and care of the child.

- Items on the attitude of the different types of staff.

- Further, items on discharge from hospital.

- Items were included on customer satisfaction.

Total 29 items.

3- Clinical examination of the child generally and local examination by inspection, palpation, percussion, auscultation.

What investigation lab, x-ray echo cath needed, how long it takes to get the investigation and are the physicians satisfied by the time it takes.

\section{Ethical committee:}

An official written administrative permission letter was obtained from Pediatric Zagazig University Hospital. The title and objectives of the study were explained to them to ensure their cooperation. The study was approved by the Ethical Committee of the Faculty of Medicine, Zagazig University. An informed consent was obtained from caregivers or parents of patients who was taken to participate in the study.

\section{Data management:}

Scoring system:

a- Socio-demographic questionnaire ${ }^{(10)}$ : The total score of socioeconomic class equals 84 , subjects were classified into 4 social classes: - Very low $<22$, - Low, from 22- 43, - Middle from $44-65$ and - High levels $\geq$ 66.

\section{b- Modified form of a generic assessment questionnaire ${ }^{(11)}$.}

\section{Statistical analysis}

All data were collected, tabulated and statistically analyzed using SPSS version 20 (Statistical Package for the Social Sciences). Age were expressed as the mean \pm SD \& median (range). Categorical qualitative variables were expressed as absolute frequencies (number) \& relative frequencies (percentage). Suitable statistical tests of significance were used after checked for normality.

The results were considered statistically significant when the significant probability was equal or less than $0.05(\mathrm{P} \leq 0.05)$. P-value $<0.001$ was considered highly statistically significant (HS), and P-value $>0.05$ was considered statistically insignificant (NS). 


\section{RESULTS}

Table (1): Socio demographic characteristics of parents of children

\begin{tabular}{|c|c|c|}
\hline Characteristic & $\begin{array}{c}\text { Frequency } \\
\mathrm{N}=106\end{array}$ & $\%$ \\
\hline $\begin{array}{l}\text { 1-Age (years) } \\
\text { Mean } \pm \text { SD } \\
\text { Range }\end{array}$ & \multicolumn{2}{|c|}{$\begin{array}{c}24.48 \pm 4.5 \\
(19-35)\end{array}$} \\
\hline $\begin{array}{l}\text { 2-Residance } \\
\text { Rural } \\
\text { Urban }\end{array}$ & $\begin{array}{l}74 \\
32 \\
\end{array}$ & $\begin{array}{l}69.8 \\
30.2 \\
\end{array}$ \\
\hline $\begin{array}{l}\text { 3Education of father } \\
\text { Illiterate } \\
\text { Secondary } \\
\text { High }\end{array}$ & $\begin{array}{l}13 \\
75 \\
18\end{array}$ & $\begin{array}{l}12.3 \\
70.8 \\
16.9\end{array}$ \\
\hline $\begin{array}{l}\text { 4- Education of mother } \\
\text { Illiterate } \\
\text { Secondary } \\
\text { High }\end{array}$ & $\begin{array}{l}14 \\
71 \\
21\end{array}$ & $\begin{array}{c}13.2 \\
67 \\
19.8\end{array}$ \\
\hline $\begin{array}{l}\text { 5-Occupation of wife } \\
\text { Not working } \\
\text { unskilled worker } \\
\text { skilled worker } \\
\text { trade }\end{array}$ & $\begin{array}{c}78 \\
4 \\
13 \\
11\end{array}$ & $\begin{array}{c}73.5 \\
3.8 \\
12.3 \\
10.4\end{array}$ \\
\hline $\begin{array}{l}\text { 6-Occupation of father } \\
\text { unskilled } \\
\text { skilled } \\
\text { trade } \\
\text { clerk }\end{array}$ & $\begin{array}{c}38 \\
29 \\
32 \\
7\end{array}$ & $\begin{array}{c}35.8 \\
27.4 \\
30.2 \\
6.6\end{array}$ \\
\hline $\begin{array}{l}\text { 7-Income } \\
\text { Not enough } \\
\text { Enough }\end{array}$ & $\begin{array}{l}81 \\
25\end{array}$ & $\begin{array}{l}76.4 \\
23.6\end{array}$ \\
\hline $\begin{array}{l}\text { 8- Social class } \\
\text { low } \\
\text { Moderate }\end{array}$ & $\begin{array}{l}59 \\
47\end{array}$ & $\begin{array}{l}55.7 \\
44.3\end{array}$ \\
\hline
\end{tabular}

This table showed that all of interviewee were patients' mothers (100\%) their mean age was 24.6 years old. Majority of interviewed parents had secondary education (70.8\% and 67\%) of fathers and mothers respectively. More than three quarters of studied group had no enough income $(76.4 \%)$ and more than half of them were of low social class $(55.7 \%)$. 
Table (2): Caretaker's view on the provided health services in Cardiology Unit at Pediatric Department, Zagazig University Hospital

\begin{tabular}{|l|c|c|}
\hline & $\mathbf{N}(\mathbf{1 0 6})$ & $\%$ \\
\hline $\begin{array}{l}\text { 1-Pre enter care } \\
\text { - as expected }\end{array}$ & 100 & 94.3 \\
- better than expected & 6 & 5.7 \\
\hline $\begin{array}{l}\text { 2- Waiting time } \\
\text { - as expected } \\
\text { - better than expected }\end{array}$ & 100 & 94.3 \\
\hline $\begin{array}{l}\text { 3- Attitude of different type of staff(polite -helpful) } \\
\text { - as expected } \\
\text { - better than expected }\end{array}$ & 6 & 5.7 \\
\hline $\begin{array}{l}\text { 4- doctor care } \\
\text {-as expected }\end{array}$ & 100 & 94.3 \\
\hline $\begin{array}{l}\text { 5-oponion about this department } \\
\text {-as expected } \\
\text {-less than expected }\end{array}$ & 106 & 5.7 \\
\hline $\begin{array}{l}\text { 6-amount of space for you and your child to stay. } \\
\text {-as expected }\end{array}$ & 100 & 100 \\
\hline $\begin{array}{l}\text { 7-bed/place where you and your child slept } \\
\text {-as expected }\end{array}$ & 6 & 94.3 \\
\hline $\begin{array}{l}\text { 8-toilet and washing facilities } \\
\text {-as expected } \\
\text { - less than expected }\end{array}$ & 106 & 5.7 \\
\hline $\begin{array}{l}\text { 9-general cleanliness of the ward } \\
\text {-as expected } \\
\text {-less than expected }\end{array}$ & 106 & 100 \\
\hline
\end{tabular}

This table showed that the satisfaction about health services and facilities was as expected, where the majority of the studied participant were satisfied about the doctor' care inside the hospital (100\%). Majority of them provided that cleanliness and washing facilities as expected (94.3\%). In addition, most of them were satisfied about attitude of different type of staff and waiting time.

Table (3): Caretaker's view on medical car in Cardiology Unit at Pediatric Department, Zagazig University Hospital

\begin{tabular}{|c|c|c|c|}
\hline & & $\mathbf{N}(\mathbf{1 0 6})$ & $\%$ \\
\hline 1-Nurse number & $\begin{array}{l}\text { - Not enough } \\
\text { - Enough }\end{array}$ & $\begin{array}{l}21 \\
85\end{array}$ & $\begin{array}{l}19.8 \\
80.2\end{array}$ \\
\hline 2- Doctor care for diagnosis & $\begin{array}{l}\text { - Not enough } \\
\text {-Enough }\end{array}$ & $\begin{array}{l}10 \\
96\end{array}$ & $\begin{array}{c}9.4 \\
90.6\end{array}$ \\
\hline 3- Nursing care in the department & $\begin{array}{l}\text {-Not enough } \\
\text {-Enough }\end{array}$ & $\begin{array}{l}26 \\
80\end{array}$ & $\begin{array}{l}24.5 \\
75.5\end{array}$ \\
\hline $\begin{array}{l}\text { 4-Doctor care after re-examination } \\
\text { on the word }\end{array}$ & $\begin{array}{l}\text {-Not enough } \\
\text {-Enough }\end{array}$ & $\begin{array}{l}15 \\
91\end{array}$ & $\begin{array}{l}14.2 \\
85.8\end{array}$ \\
\hline 5-Treatment & $\begin{array}{l}\text {-Not enough } \\
\text {-Enough }\end{array}$ & $\begin{array}{l}30 \\
76\end{array}$ & $\begin{array}{l}28.3 \\
71.7\end{array}$ \\
\hline
\end{tabular}

This table showed that majority of parents found that the provided medical care was enough especially nurse number $(80.2 \%)$ doctor' care for diagnosis $(90.6 \%)$, nursing care $(75.5 \%)$ and treatment $(71.7 \%)$.

Table (4): General satisfaction of caretaker's about children health care service in cardiology unit at pediatric department of Zagazig University Hospital

\begin{tabular}{|l|c|c|}
\hline \multicolumn{1}{|c|}{ Parents satisfaction } & $\mathbf{N}(\mathbf{1 0 6})$ & $\%$ \\
\hline \hline -Very satisfied & 5 & 4.7 \\
- Satisfied & 95 & 89.6 \\
- Not satisfied & 6 & 5.7 \\
\hline
\end{tabular}

This table showed that $89.6 \%$ of parents were generally satisfied about children health care services. 
Table (5): Association between caretaker's satisfaction and their socio-demographic characteristics

\begin{tabular}{|c|c|c|c|c|c|c|c|c|}
\hline \multirow{3}{*}{$\begin{array}{l} \\
\\
\text { Age (years): } \\
<30 \\
\geq 30\end{array}$} & \multicolumn{2}{|c|}{$\begin{array}{c}\text { Very satisfied } \\
\mathbf{N}(5)\end{array}$} & \multicolumn{2}{|c|}{$\begin{array}{l}\text { Satisfied } \\
\text { N(95) }\end{array}$} & \multirow{2}{*}{\multicolumn{2}{|c|}{$\begin{array}{c}\begin{array}{c}\text { Not satisfied } \\
\mathbf{N}(6)\end{array} \\
\mathrm{N} \%\end{array}$}} & \multirow{3}{*}{$\begin{array}{c}\chi^{2} \\
1.36 \\
\end{array}$} & \multirow{3}{*}{$\begin{array}{c}\mathrm{P} \\
.751\end{array}$} \\
\hline & \multirow{2}{*}{$\begin{array}{l}\mathrm{N} \\
\\
3 \\
2\end{array}$} & \multirow{2}{*}{$\begin{array}{l}\% \\
60 \\
40\end{array}$} & \multirow{2}{*}{$\begin{array}{l}\mathrm{N} \\
\\
52 \\
43\end{array}$} & \multirow{2}{*}{$\begin{array}{c}\% \\
54.7 \\
45.3\end{array}$} & & & & \\
\hline & & & & & $\begin{array}{l}4 \\
2 \\
\end{array}$ & $\begin{array}{l}66.7 \\
33.3 \\
\end{array}$ & & \\
\hline $\begin{array}{l}\text { Education of mother } \\
\text { Illiterate } \backslash \text { Read \& write } \\
\text { secondary } \\
\text { High }\end{array}$ & $\begin{array}{l}1 \\
3 \\
1\end{array}$ & $\begin{array}{l}20 \\
60 \\
20\end{array}$ & $\begin{array}{l}13 \\
63 \\
19\end{array}$ & $\begin{array}{c}13.7 \\
66.3 \\
20\end{array}$ & $\begin{array}{l}0 \\
5 \\
1\end{array}$ & $\begin{array}{c}0 \\
83.3 \\
16.7\end{array}$ & 1.29 & $0.86^{*}$ \\
\hline $\begin{array}{l}\text { Education of father: } \\
\text { Illiterate } \backslash \text { Read \& write } \\
\text { secondary } \\
\text { High }\end{array}$ & $\begin{array}{l}1 \\
3 \\
1\end{array}$ & $\begin{array}{l}20 \\
60 \\
20\end{array}$ & $\begin{array}{l}12 \\
67 \\
16\end{array}$ & $\begin{array}{l}12.6 \\
70.5 \\
16.9\end{array}$ & $\begin{array}{l}1 \\
4 \\
1\end{array}$ & $\begin{array}{l}16.7 \\
66.7 \\
16.7\end{array}$ & 0.37 & $0.98 *$ \\
\hline $\begin{array}{l}\text { Income: } \\
\text { Not enough } \\
\text { Enough }\end{array}$ & $\begin{array}{l}5 \\
0\end{array}$ & $\begin{array}{c}100 \\
0\end{array}$ & $\begin{array}{l}74 \\
21\end{array}$ & $\begin{array}{l}77.9 \\
22.1\end{array}$ & $\begin{array}{l}2 \\
4\end{array}$ & $\begin{array}{l}66.7 \\
33.3\end{array}$ & 7.84 & $.02 *$ \\
\hline $\begin{array}{l}\text { Social class: } \\
\text { low } \\
\text { moderate }\end{array}$ & $\begin{array}{l}3 \\
2\end{array}$ & $\begin{array}{l}60 \\
40\end{array}$ & $\begin{array}{l}52 \\
43\end{array}$ & $\begin{array}{l}54.7 \\
45.3\end{array}$ & $\begin{array}{l}4 \\
2\end{array}$ & $\begin{array}{l}66.7 \\
33.3\end{array}$ & 0.37 & $0.83 *$ \\
\hline $\begin{array}{l}\text { Residence: } \\
\text { Rural } \\
\text { Urban }\end{array}$ & $\begin{array}{l}5 \\
0\end{array}$ & $\begin{array}{c}100 \\
0\end{array}$ & $\begin{array}{l}65 \\
30\end{array}$ & $\begin{array}{l}68.4 \\
31.6\end{array}$ & $\begin{array}{l}4 \\
2\end{array}$ & $\begin{array}{l}66.7 \\
33.3\end{array}$ & 2.28 & .320 \\
\hline
\end{tabular}

*statistically significant $(\mathrm{p}<0.05) \chi^{2}$ : Chi-square test.

This table showed statistically non-significant difference between parents' satisfaction and socio-demographic characteristics $(p>0.05)$ except for income in which not enough income was very satisfied $(\mathbf{p}<\mathbf{0 . 0 2})$.

Table (6): Health care providers' opinion about the commonest risk factors associated with children's death in Cardiology Unit, Zagazig University Hospital

\begin{tabular}{|l|c|c|}
\hline & $\mathbf{N}(\mathbf{2 0})$ & $\%$ \\
\hline 1-Nature of the disease & 5 & 25 \\
-Yes & 15 & 78 \\
-No & 2 & 10 \\
\hline 2- Late presentation of children & 18 & 90 \\
-Yes & & \\
-No & 0 & 0 \\
\hline 3-Problems with laboratorydiagnosis & 20 & 100 \\
-Yes & 1 & 5 \\
-No & 19 & 95 \\
\hline 4- Insufficient drugs & 7 & 35 \\
-Yes & 13 & 65 \\
-No & & \\
\hline 5- Inadequate equipments & 0 & 0 \\
-Yes & 20 & 100 \\
-No & & 0 \\
\hline 6- Lack of staff for care andmonitoring & 0 & 100 \\
-Yes & 20 & \\
-No & & \\
\hline 7- Wrong treatment given & & \\
-Yes & & \\
-No & & \\
\hline
\end{tabular}

Table (6) showed that health care providers' opinion about the commonest risk factors associated with children's death in Cardiology Unit were 5\% due to nature of disease, $2 \%$ due to late presentation, $5 \%$ 
insufficient drugs and $35 \%$ inadequate equipment.

Table (7): Association between patients' parents' satisfaction and their severity of disease

\begin{tabular}{|c|c|c|c|c|c|c|c|c|}
\hline \multirow{3}{*}{\begin{tabular}{|l|} 
\\
$\begin{array}{l}\text { Chest infection only (pneumonia - } \\
\text { bronchiolitis }\end{array}$ \\
\end{tabular}} & \multicolumn{2}{|c|}{\begin{tabular}{|c|} 
Very satisfied \\
$\mathrm{N}(5)$
\end{tabular}} & \multicolumn{2}{|c|}{$\begin{array}{l}\text { satisfied } \\
\mathbf{N}(95) \\
\end{array}$} & \multirow{2}{*}{\multicolumn{2}{|c|}{$\begin{array}{c}\text { Not satisfied } \\
\text { N (6) } \\
\text { N \% } \\
\end{array}$}} & \multirow[t]{2}{*}{$\chi^{2}$} & \multirow[b]{2}{*}{$\mathrm{P}$} \\
\hline & $\mathrm{N}$ & $\%$ & $\mathrm{~N}$ & $\%$ & & & & \\
\hline & 2 & 1.9 & 41 & 38.7 & 4 & 3.8 & 1.45 & .651 \\
\hline $\begin{array}{l}\text { Chest infection associated with } \\
\text { Congenital heart disease }\end{array}$ & 0 & 0 & 2 & 1.9 & 0 & 0 & 1.567 & $.02 *$ \\
\hline Congenital heart disease & 0 & 0 & 2 & 1.9 & 0 & 0 & 1.567 & $.02 *$ \\
\hline Heart failure & 0 & 0 & 21 & 19.8 & 0 & 0 & 6.184 & $.02 *$ \\
\hline Anemic heart failure & 1 & .9 & 3 & 2.8 & 1 & .9 & 7.365 & $.01 *$ \\
\hline
\end{tabular}

*statistically significant $(\mathrm{p}<0.05)$

$\chi^{2}$ :Chi-square test

This table showed statistical significant difference between parents' satisfaction and their severity of disease $(p>0.05)$.

\section{DISCUSSION}

High patients' satisfaction is associated with more confidence in health care providers, increased compliance with treatment and therefore better quality of life. So, this study aimed to improve the quality of health care in Pediatric Cardiac Unite in Zagazig University hospitals, by assessing the level of patient' satisfaction and determining factors affecting it. A cross sectional study was carried out on 106 patients attending the Pediatric Cardiac Unit at Zagazig University Hospital. The studied participant had mean age $24.48 \pm 4.5$ years.

Their mean age was 24.6 years old. Majority of interviewed parents had secondary education $70.8 \%$ and $67 \%$ of fathers and mothers respectively. More than three quarters of studied group had no enough income (76.4\%) and more than half of them were of low social class $(55.7 \%)$. This is in accordance with El sherbiny et al. (12) who found that $47.9 \%$ were of secondary education, and Ismail and Essa ${ }^{(13)}$ who found that $30 \%$ of the participants were illiterates and $30 \%$ were of secondary education. More than three quarters of studied group had no enough income (76.4\%) and more than half of them were of low social class (55.7\%). Most of patients $(69.8 \%)$ were rural residents unlike that was found in a study carried out in Pakistan by Amman and Abbas ${ }^{(14)}$ who found that $69.4 \%$ were from urban areas.

Regarding patients' satisfaction generally about children health care services was $89.6 \%$. This is in accordance with a study carried out at Saudi Arabia comparing $\mathrm{MOH}$ and private hospital where the satisfaction for them were $56 \%$ and $70 \%$ respectively (15), and a study carried out in China where the satisfaction was $78 \%{ }^{(16)}$. The reason of the relatively high level of satisfaction about environment and facilities may be attributed to that most of the studied participants were of low social class. On the other hand, the results of the current study were in contrary to Ismail and Essa ${ }^{(13)}$ which revealed that $62.9 \%$ of study subjects were generally dissatisfied. Moreover, a study carried out in Pakistan where the satisfaction was $48 \%$ (14). This may be due to the low socioeconomic status of our studied participants as most of them were of low social class, which made them more satisfied.

In the current study, it was found that most of the studied participants were satisfied about the site of the hospital and cleanliness $(62.3 \%$ and $100 \%$ respectively). This is in accordance with a study carried out in Fayoum University where, 59.2\% were satisfied about the hospital location, $85.9 \%$ were satisfied about cleanliness and $76.4 \%$ said that the waiting area lacked proper facilities ${ }^{(12)}$. On the other hand, it was in disagreement to a study carried out in mother care health $(\mathrm{MCH})$ centers affiliated to Ministry of Health in ElBeheira Governorate, which found that $63.4 \%$ of the study subjects were dissatisfied with the hospital location (13). The satisfaction about the site of the hospital may be attributed to the availability of different types of transport and presence of Zagazig University Hospitals in the center of the town. In addition, the high level of dissatisfaction about facilities is mainly due to the crowdedness of the inpatient clinics and unavailability of seats for all patients due to the high attendance rate and the unavailability of source of near drinking water.

This study showed that the satisfaction about waiting time was $94.3 \%$, while it was $60 \%$ in a study carried out in Saudi Arabia by Al Fraihi and Latif (17) and $74 \%$ in a study carried out in China by $\mathbf{Y u}$ et al. ${ }^{(16)}$. On the other hand, Ismail and Essa ${ }^{(13)}$ results are not similar to the current study in that $80 \%$ of studied patients were dissatisfied with the services timing. The dissatisfaction about the waiting time and reservation is mainly attributed to the over crowdedness as most of the patients usually come early to cut and register their tickets as cutting tickets is closed at $12 \mathrm{pm}$, also due to lack of organization and due to lack of culture of commitment to the order.

Regarding patients' satisfaction about treatment, it was found that $28.3 \%$ were dissatisfied about treatment availability, while $71.7 \%$ were satisfied. This is almost 
similar to a study carried out by Awad Allah et al. ${ }^{(18)}$ at Zagazig University Hospitals Dental Clinic, where $66.2 \%$ of studied participants were satisfied about treatment.

In the current study, it was found that more than three quarters of the studied participants were satisfied about consultation time (care for diagnosis) (90.6\%), this is in accordance with study carried out at Saudi Arabia, where the satisfaction about consultation time was $67 \%{ }^{(17)}$. In addition, a study carried out in Demerdash and Ain Shams University Hospitals, Chest Outpatient Clinic where $83.7 \%$ \& $81.8 \%$ of the studied participants were satisfied about consultation time ${ }^{(19)}$. This is in disagreement with El sherbiny et al. ${ }^{(\mathbf{1 2})}$ who carried out a study in Fayoum University, where 93.3\% of the studied participants claimed that the physician did not stay with them enough time for examination. Moreover, Ismail and Essa ${ }^{(13)}$ found that $83.4 \%$ were dissatisfied with the counseling time. In addition, a study carried out at Qassim University by Alzolibani (20) found that only $48 \%$ of patients felt that consultation time is inadequate.

Regarding satisfaction about nurses, this study showed that the satisfaction about nurses at Zagazig University Hospital Pediatric Cardiac Unite was 75.5\%. This is supported by Kol et al. ${ }^{(21)}$ who carried out a study in Turkey, where the satisfaction about nurses was $62.1 \%$. Also, a study carried out in Saudi Arabia in MOH hospital and private hospital by Jadelhack (15) where the satisfaction about nurses were $66 \%$ and $70 \%$ respectively. In addition, a study carried out in china where the satisfaction about nurses was $84 \%{ }^{(16)}$.

The current study showed that there was high statistical significant association between age and total satisfaction level where younger mother tend to be more satisfied. This is in agreement with Diab ${ }^{(19)}$ who stated that younger patients were more likely to be satisfied with the provided healthcare services. In addition, Alzolibani ${ }^{(20)}$ stated that patients aged below 40 were significantly more satisfied than older patients were. While this is in contrary with Mitropoulos et al. (22) who carried out a study in Greece where the older age patients were significantly associated with higher satisfaction. This also disagrees with $\mathbf{Y u}$ et $\boldsymbol{a l} .{ }^{(16)}$ and De Salins et al. ${ }^{(23)}$ who reported the same results. This could be explained by that the older patients are accustomed to low level of services while younger patients are more open to new technologies.

The current study claimed that there was significant association between education level and social class with overall satisfaction, where illiterate, secondary, highly educated patients and patients with low socioeconomic level were more satisfied. This could be explained by low cost of service, and that the illiterate patients accept any level of service, and that the highly educated know well that it is a free service so they accept it as it is. This is in accordance with other studies like Alzolibani ${ }^{(20)}$ and Yu et al. ${ }^{(16)}$, while in contrary to Diab ${ }^{(19)}$ who found that there was no statistical significance association between level of education and satisfaction. Moreover, these results are in disagreement with other studies, which found no significant association between total satisfaction level with age, sex, education level in different countries like Kol et al. ${ }^{(21)}$ in Turkey, Jadelhack ${ }^{(15)}$ in Saudi Arabia and Kuteyi et al. ${ }^{(24)}$ in Nigeria.

Gender was not significantly associated with satisfaction as reported by Mitropoulos et al. ${ }^{(22)}$ and De Salins et al. ${ }^{(23)}$.

This study showed that there was high statistical significant association between total satisfaction and satisfaction about environment, doctors, nurses and information given for patients. This is supported by Mitropoulos $\boldsymbol{e t}$ al. ${ }^{(22)}$ who stated that communication with nurses and doctors, the physical environment and information given for patients had statistically significant association with total satisfaction. In addition, Yu et al. ${ }^{(16)}$ stated the same results.

\section{CONCLUSION}

It was concluded that not only quality domains can affect the level of patient satisfaction but also there are factors not related to the hospital can affect it as sociodemographic factors. It is proved that age, sex, education, occupation and social class can affect level of patient satisfaction. In addition, it has been concluded that the level of patient satisfaction can shape the patients' loyalty to the hospital, as the higher the patient satisfaction, the higher the patient loyalty represented in their intention to re-use and recommend Zagazig University Hospital to others. Improvement of service procedure must be taken in consideration.

\section{REFERENCES}

1. Donabedian A (1980): Explorations in Quality Assessment and Monitoring. Ann Arbor, MI: Health Administration Press, $\quad$ 5-6. https://www.scirp.org/(S(i43dyn45teexjx455qlt3d2q))/ref erence/ReferencesPapers.aspx?ReferenceID=960287

2. Roemer M, Montoya-Aguilar C (1988): Quality Assessment and Assurance in Primary Health Care. WHO Offset Publication No., 105, World Health Organization, Geneva, Switzerland. https://apps.who.int/iris/handle/10665/40663

3. Morrow E, Ross F, Grocott P (2010): A model and measure for quality service user involvement in health research. International Journal of Consumer Studies, 34: 532-7.

4. Bolus R (1999): Patient satisfaction: the indispensable outcome. Managed Care, 8: 24-8.

5. Keiza E, Chege M, Omuga B (2017): Assessment of parents' perception of quality of pediatric oncology inpatient care at Kenyatta National Hospital. Asia Pac J Oncol Nurs., 4: 29-33.

6. Muntlin A, Gunningberg L, Carlsson M (2006): Patients' perceptions of quality of care at an emergency department and identification of areas for quality improvement. J Clin Nurs., 15: 1045- 56. 
7. Haj-Ali W, Karroum L, Natafgi N et al. (2014): Exploring the relationship between accreditation and patient satisfaction - the case of selected Lebanese hospitals. Int J Health Policy Manag., 3 (6): 341-346.

8. McDonald K, Sundaram V, Bravata D et al. (2007): Closing the Quality Gap: A Critical Analysis of Quality Improvement https://www.ncbi.nlm.nih.gov/books/NBK44015/

9. Ygge B (2004): Parental Involvement in Paediatric Hospital Care- Implications for Clinical Practice and Quality of Care. Journal of Nursing Management, 12: 512.

10. El-Gilany A, El-Wehady A, El-Wasify M (2012): Updating and validation of the socioeconomic status scale for health research in Egypt. East Mediterr Health J., 18: 962-5.

11. World Health Organization (WHO) (2008): How does satisfaction with the health-care system relate to patient experience?

https://www.who.int/bulletin/volumes/87/4/07050401/en/

12. El Sherbiny N, Labib N, El Derwi D et al. (2015): Patient's a Health Care Provider Satisfactions with OutPatients Clinics System in Fayoum University Hospital. MOJ Public Health, 3 (2): 59-66.

13. Ismail N, Essa R (2017): Pregnant Women's Satisfaction with the Quality of Antenatal Care at Maternal and Child Health Centers in El-Beheira Governorate. IOSR Journal of Nursing and Health Science, 6 (2): 36-46.

14. Aman B, Abbas F (2016): Patient's perceptions about the service quality of public hospitals located at District Kohat. J Pak Med Assoc., 66 (1): 72-75.

15. Jadelhack R (2014): Assessment of a patient satisfaction survey and its relationship to hospital sector and nurses' level of education in one region in Saudi Arabia. Pro Quest LLC., 2: 1-136.
16. Yu W, Li M, Xue C et al. (2016): Determinants and influencing mechanism of outpatient satisfaction: a survey on tertiary hospitals in the People's Republic of China. Patient Preference and Adherence, 10: 601-612.

17. Al Fraihi K, Latif S (2016): Evaluation of outpatient service quality in Eastern Saudi Arabia. Saudi Med J., 37 (4): 420-428.

18. Awad Allah M, Eltwansy M, El-Shafe D (2017): Patient Satisfaction at Dentist Clinic in Zagazig University Hospitals Egypt. Public Health International, 2 (4-1): 1-6.

19. Diab H (2015): Assessment of patients' satisfaction in Ain Shams University Hospitals. Egypt J Broncho., 9: 211-220.

20. Alzolibani A (2011): Patient satisfaction and expectations of the quality of service of University affiliated dermatology clinics. Journal of Public Health and Epidemiology, 3 (2): 61-67.

21. Kol E, Arıkanb F, Ilaslanc E et al. (2018): A quality indicator for the evaluation of nursing care: determinationof patient satisfaction and related factors at a university hospital in the Mediterranean Region in Turkey. Collegian, 25: 51-56.

22. Mitropoulos P, Vasileiou K, Mitropoulos I (2018): Understanding quality and satisfaction in public hospital services: A nationwide inpatient survey in Greece. Journal of Retailing and Consumer Services, 40: 270 275.

23. De Salins C, Brenaut E, Misery L et al. (2016): Factors influencing patient satisfaction: assessment in outpatients in dermatology department. JEADV., 30: 1823-1828.

24. Kuteyi A, Bello I, Olaleye T et al. (2010): Determinants of patient satisfaction with physician interaction: a crosssectional survey at the Obafemi Awolowo University Health Centre, Ile-Ife, Nigeria. SA Fam Pract., 52 (6): 557- 562 . 